\title{
Care work and Time Use: A focus on Child Care, Personal Care, and Elderly Care time
}

Volume: 7

Issue: 2

Month: March

Year: 2019

ISSN: 2319-961X

Received: 5.2.2019

Accepted: 11.3.2019

Published: 15.3.2019

\section{Citation:}

Ramya, R. "Care Work and

Time Use: A Focus on Child

Care, Personal Care, and

Elderly Care Time." Shanlax

International Journal of

Economics, vol. 7, no. 2,

2019, pp. 34-41.

DOI:

https://doi.org/10.34293/

economics.v7i2.306

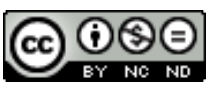

This work is licensed under a Creative Commons Attribution-NonCommercialNoDerivatives 4.0 International License

\section{R.Ramya}

Assistant Professor of Economics

Sri C. Achutha Menon Government College, Thrisur, Kerala, India

\begin{abstract}
Today the concept of 'time poverty' is gaining much attention. Since time is a limiting factor, when more of it is devoted to paid and unpaid work, less time is available for leisure, which results in high time poverty. Time is a natural and universal concept which is more precious than money. A woman's position in the society and family, as well as her time allocation, is a multi-dimensional phenomenon. Therefore, a woman's paid works as well as her unpaid domestic work, especially care work are equally significant as it produces profound influence upon her time allocation. Across the globe, women and girls do the vast majority of care work in the home which creates disproportional responsibilities finally result in time poverty. This paper mainly focuses on the care time (child care, elderly care and personal care time) devoted by working women across different occupations.
\end{abstract}

Keywords: Time poverty, Care time, Child care, Elderly care, Personal care

\section{Introduction}

The household is a 'time greedy institution' (Coser, 1974). When there are young children and the number of children increases, demand for domestic time also increases and as a result, the household turns to become a time greedy institution. But often the labor of housewife goes unnoticed as shadow work; they are not seen to be part of the economy (Susan Viswanathan, 1996). Occupation and its various classifications are essential in the examination of time use because in the organized sector they have fixed working hours, but in the case of those working in the informal or unorganized sector time use pattern is very complicated as their work time is not correctly specified. The new occupational classification based on NCO (National Classification of Occupations) 2004 is used for the present study. As geography has a significant role in time use surveys as revealed by CSO's time use survey, the central most district in Kerala that is the Thrissur district was selected as the sample area. The study area is thus confined only to Thrissur district which covers Thrissur Corporation, Kodungallur Municipality, Valappad Panchayat, and Pazhayannur Panchayat. The area selected is comprised of geographical features namely highly urbanized, semi-urban, coastal belt and hilly terrain. To focus an urban setting Thrissur Corporation and Kodungallur Municipality, a rural setting Pazhayannur Panchayath and Valappad Panchayath are selected. 


\section{Child Care Time}

Child care constitutes the most time consuming, and most significant part of the time budget studies and was bought to the attention of economists and sociologists. One of the significant findings of the earlier studies reveals that women's employment and the presence of preschool children are the decisive factors which influence the time allocation between paid and unpaid work. Children were considered as a home time-intensive activity (Willis, 1973). As children are introduced to the household, they become home time intensive activity. This creates major influence on the energy, work and time of women. Gronau (1977) compares the wife's time to an iceberg, the visible top shows the time she spends in the market, but the submerged part is just like the amount of time she spends at home. Traditionally, women's work has been confined to the act of procreation, and it includes only child bearing and child rearing which has to be performed along with domestic work. But if her outside work increases due to an increase in wage rate profitability of home production activity decreases and family rely solely on market goods.

Regarding child care in the economics of the family, Becker $(1974,1981)$ explains the number of children a couple may want, skill, knowledge, and socialization called quality and development level, which parents wish their children to attain. The greater the difference between the education of husband and wife, the weaker is the substitution relationship in the couple's time. If we value time on the basis of market wage which is directly proportional to the educational level, an increase in husband's education results in the supply of more time for his market work and a corresponding decline in the market work of women. As a result, she has to spend more of her time on domestic work.

The time allocation of men and women for market and nonmarket activities was calculated by considering child care also. A study conducted in the mountainous district of Humla in North West Nepal revealed that due to its primitive agricultural background, more men went outside in search of better jobs which levied excess burden on the shoulders of women. They had to combine heavy domestic work, agricultural duties along with child care. After a few weeks of delivery, due to heavy work pressure women had only less time available to look after their infants. Supplementation of breast milk with other food supplements and use of substitute care takers occurred, and such heavy work of women produced an adverse effect upon her health (Le Vine, 1987). It also implies that if childcare duties are transformed to the market without loss of parental satisfaction, then the link between the opportunity value of the parents time and the shadow price of children would be partially broken (Schultz,1986). He also found that in traditional nuclear families in which wife specialize in nonmarket production activities and an increase in her market wage relation to men leads to downward pressure in the fertility rate. There is also a tendency to shift some of the child care duties to lower cost providers in the market. It is true that men also began to enter into more child care activities. But now too, women shoulder the prime responsibility of childcare. All the above-stated studies throw light on the time poverty faced by women across societies.

Traditionally, the father was considered as the sole breadwinner of the family, and his wife as the exclusive provider of child care, and performer of domestic duties. Mother's employment has changed the situation and her control over financial resources has made changes in the familial roles. Becker (1985) argues that mothers have to choose occupations compatible with rearing their children. Mothers of young children, due to their participation in income generating activities had to curtail the time spent on child care. They are compelled to work outside, due to their economic necessity, and the same compels them to make efficient and proper use of their scarce resource, i.e. time. Women who work as sales girl, maids, etc. have to spend more time at the work area, and the income they gain from such occupations is comparatively low. They have to spend the early morning and late evening hours in the job site for which no extra money is paid. Sometimes working in evenings and nights considered as inferior, even if the same work possess different cost at different times (Hamermesh,1998). Along with such low paid occupations, some women are engaged in homebased industries which include pickle making, basket weaving, making sandwiches, etc. along with their domestic duties. All this highlights the significance of the time allocation pattern of working women. 
If they are in well-paid jobs, employed mothers do less household work and less time will be spent on child care, sleep, and leisure. All these create the problem of 'family gap' (Waldfogel, 1997). Similarly, an increase in employed mothers may be leading to the decline in social capital in the family and the society (Coleman, 1988). When a woman enters into the labor force, the opportunity cost of her time devoted to domestic work increases. The result is the shortage of time parted for household activities like cooking and child care. To fill the time gap, she seeks a substitution by a domestic worker.

Women's earnings are adversely affected by household responsibilities, the heavy burden of household work, caring for sick and elderly in the household, child care, other emergencies, all causing a deterioration of her potential energy which adversely affects her labor market opportunities. Allocation of energy is affected by its intensity in different activities. The total energy at the disposal of a person during any period can be altered by the production of energy and by its reallocation over the life cycle (Becker, 1985). Employer requires time and vigour of the employees. If both of these are extensively used for the households, less of it is available for the market work. Since childcare requires more time and energy, women who intensively indulge in child care may seek jobs with less effort.

Sleep constitutes the highest time consuming single activity (Biddle and Hamermesh, 1990). When more females are entering into labor market along with no change in the time spent on domestic chores, less time is available for sleep. Price of time varies among individuals. Evidence show that women sleep more than men (Klietman, 1963). But in the reality, the presence of young children, heavy household duties and market work reduces the sleeping time of women compared to men. Also, an increase in education reduces sleep duration. Sleep is also considered as an essential ingredient since enough and sufficient sleep adds to individual's productivity and in turn to their efficiency which will lead to the maximization of money income (Becker1965, p-498). Most of the time use studies divide the total time of the individual into time spend to paid work, and to unpaid domestic work and leisure (and often neglects sleep which consumes a major share of time). Therefore along with leisure, time use researchers should consider the significance of sleep.

Time devoted to personal care is another significant aspect of time use. Considering the time use studies of 1975 and 1976 by Kooreman and Kapteyn (1987, p-241), we can understand that the woman substantially reduces the amount of time spent on personal care if their wage rate goes up. How many women due to their tight work schedules get enough and sufficient time for personal care including physical exercises? Even though they gather money from market work, lack of time for personal care is in fact a neglect of their own self. Thus the care for themselves is thus a significant variable that influences the time allocation pattern of working women.

A detailed picture of time allocation and its influence on consumer durables was given by Bowden and Offer (1994). While examining the time allocation of working women, the role played by time-saving consumer durables is significant. Time allocation between market goods and house hold work depends on their marginal productivity. Within the household women often deal with two types of goods, i.e. time using and time-saving, time using products require the use of discretionary time in conjunction with the product (television, radio), and time-saving goods are those which reduces and saves their precious time (cooker, cleaner). The saved time thus can be utilized in the labor market to enhance their income. Becker considers consumer durables as an input to household production indirectly.

A better work- family balance is essential for the welfare and development of the family and also for the creation of a peaceful nation. Zuzanek and Wenger (2002) and Ezra and Deckman (1996) point out that flex time schedules are more suited for a woman. They found out that under modern service sector jobs including the IT sector, women have to perform 10-12 hours of tight work because of their compressed work schedules. To maintain proper work-family balance, flexible work schedules are more suitable for women rather than compressed ones. Increase in the wage rate of the husband compels him to spend more time in the market work and as a substitute to this; wife has to increase her 
domestic duties by reducing her market commitment. Educated ones prefer market work, and if they have young children, it increases her domestic work but reducing their leisure time (Malathy 1998, Bianchi 2006).

One important aspect related to the present study is that woman's time allocation to child care varies according to personal and labor market characteristics (Miller and Mulvey, 2000). They found that bettereducated mothers spend more time for child care and such a finding lean towards the results found in the present data analysis where a working woman who had better education and well-paid jobs realize the significance of child care and give care work its due importance. Similarly, Immaculada et al $(2009,2011)$ analyze intra household time allocation in Denmark, France, Germany, Italy and Spain considering data from European Community Household Panel (ECHP 1994-2001) and found that conspicuous inequality in hourly time devoted to child care by parents and those parents with young children, more time was given to care work. Women were noted for their love and affection as mothers, and child care often consume an incredible portion of the time of woman especially that of a working woman. For analysis I divided total child care provided by a woman into three:

- $\quad$ Primary child care (which include breast feeding, general feeding, bathing, changing diapers dress, medical care, rocking a child to sleep and so on)

- $\quad$ Educational child care (which include helping children to do homework, reading for children, attending meetings in school and so on.

Recreational child care (which include time spend by playing games with children, going outdoor and so on).

Care time of working woman across different occupations is given in table 1 .

Table 1 Child Care Time Allocation (in hours) across Occupational Status

\begin{tabular}{|c|l|c|c|c|}
\hline S.No & \multicolumn{1}{|c|}{ Occupational Divisions } & $\begin{array}{c}\text { Primary } \\
\text { child care }\end{array}$ & $\begin{array}{c}\text { Educational } \\
\text { child care }\end{array}$ & $\begin{array}{c}\text { Recreational } \\
\text { child care }\end{array}$ \\
\hline 1 & Legislators, Senior officials, and managers & 0.02 & 0.62 & 0.07 \\
\hline 2 & Professionals & 0.22 & 0.00 & 0.00 \\
\hline 3 & Technicians and Associate professionals & 0.66 & 0.76 & 0.40 \\
\hline 4 & Clerks & 0.30 & 0.77 & 0.19 \\
\hline \multirow{2}{*}{5} & $\begin{array}{l}\text { Service workers and Shop \& market sales } \\
\text { workers }\end{array}$ & 0.20 & 0.73 & 0.27 \\
\hline 6 & Skilled Agricultural and Fishery workers & 0.08 & 0.71 & 0.19 \\
\hline 7 & Craft and related workers & 0.22 & 0.33 & 0.14 \\
\hline 8 & Plant and machine operators and Assemblers & 0.17 & 0.67 & 0.25 \\
\hline 9 & Elementary occupations & 0.12 & 0.38 & 0.07 \\
\hline 10 & Workers not classified by occupations & 0.53 & 0.73 & 0.35 \\
\hline \multirow{2}{*}{ F-value } & $\mathbf{1 . 8 7 n s}$ & $\mathbf{1 . 8 4 5 n s}$ & $\mathbf{1 . 8 0 1 n s}$ \\
\cline { 2 - 5 } & P-value & $\mathbf{0 . 0 5 4}$ & $\mathbf{0 . 0 5 8}$ & $\mathbf{0 . 0 6 6}$ \\
\hline
\end{tabular}

ns - nonsignificant at 0.05 levels

Values presented in the table are average or mean value of time (per day) in hours.

\section{Source: Sample survey}

The $\mathrm{F}$ value reveals that there is no significant difference between different occupational groups in providing child care, as it is clear that women whatever be their occupational status spend almost a similar time for child care. But regarding professionals, the mean value of time per day (in hours) spent on educational and recreational child care approaches zero. It reveals that they face high time poverty due to their tight work schedules as is clear from the questionnaire. In the case with 
educational time care which include helping children to do their homework, reading study materials for children, etc consumes a lot of time and among professionals basically that of medical professionals like gynecologists, surgeons, nursing professionals, designers, etc appoint a substitute teacher to look after their children's educational needs because they had with them less time to play outdoor and indoor with their children. Another reason to gain a low time spent for educational and recreational child care by the professionals is that majority of those working woman in the sample who came under this occupational class have children above 15 years of age where such care and time devoting to such care has a little significance. One significant feature is that only a slight variation in child care time across different occupations was noticed. They also reveal that they arrange a paid teacher at home to give their children educational assistance, and similarly they gain only minimal time to play with their children and to go outside with them and this too put the mean value near to zero.

\section{Personal Care time}

As a general notion women spend more time on personal care and Indian time use survey, 2000 reveal that it is men and not women who spend more time on personal care. Here in the sample data analysis, it is found from table 1.2 that the $\mathrm{F}$ value is nonsignificant. It reveals that there exists no significant difference between occupational groups in the time devoted to personal care. A slight difference can be noticed in the case with professional and associate professionals who spend somewhat a little bit time more than other occupational categories in the time spent on personal care.

Table 2: Time allocation (in hours) for personal care across occupational status

\begin{tabular}{|c|l|c|}
\hline S.No & \multicolumn{1}{|c|}{ Occupational Divisions } & Personal care time \\
\hline 1 & Legislators, Senior officials, and managers & 0.95 \\
\hline 2 & Professionals & 1.16 \\
\hline 3 & Technicians and Associate professionals & 1.10 \\
\hline 4 & Clerks & 0.87 \\
\hline 5 & Service workers and Shop \& market sales workers & 0.93 \\
\hline 6 & Skilled Agricultural and Fishery workers & 0.83 \\
\hline 7 & Craft and related workers & 0.97 \\
\hline 8 & Plant and machine operators and Assemblers & 0.75 \\
\hline 9 & Elementary occupations & 0.85 \\
\hline 10 & Workers not classified by occupations & 1.03 \\
\hline & F-value & $1.521 \mathrm{~ns}$ \\
\cline { 2 - 3 } & P-value & 0.138 \\
\hline
\end{tabular}

ns - non significant at 0.05 level

Values presented in the table are average or mean value of time (per day) in hours.

Source: Sample survey

The Indian time use survey, 2000 revealed that it is the males spend more time on their personal care and health care related activities than their partners. In Kerala too the same pattern follows. The above data revealed that irrespective of the educational and occupational attainment of a large number of women in Kerala there exists the traditional male-dominated social structure in majority of the households. An egalitarian approach to decision making within the household is not much popular in households, but compared to the past years females' role in decision making has shown a better trend.

\section{Elderly Care Time}

India is the second populous country in the world, with 99.87 million persons above 60 years of age, 
constituting $8.3 \%$ of the total population (Census of India, 2011). Elderly and elderly related issues are so significant in a country where the elderly occupies a high proportion. Population aging is thus the end product of demographic transition, and Kerala which passes through the third stage of demographic transformation always faces the problem of aging in its severity. Elderly dependency figures reveal that the proportion of elders is increasing substantially and Kerala (16.5 percent) stood first among Indian states in terms of elderly dependency, and it is even higher than the national average (13.1 percent).

Population aging is one of the demographic changes is noticed around the world. In Kerala with high life expectancy, population aging, and its related effects are more prominent. The increased number of elderly in every household together with increased women participation in market work increases the total work load of working women. The illnesses of any one of the family members have a significant impact on household members' time and income. If the elderly members in the household are weak or bedridden, it will surely increase the working woman's time spent on domestic work including elderly care. Yamada and Yamada (1993) found that an increase in market wage for both young and elderly households reduces their time spend on nonmarket activities like child care, medical care and other leisure activities like watching television and listening to the radio. In Kerala problems related to demography is noticeable as the proportion of the aged population is increasing compared to that of the child population. Thus elderly and elderly care has a significant influence upon working woman's time allocation. Traditional notion is that it is a woman's duty to look after the elderly members in the household and now too whatever be their occupational status they spend time for elderly care. Table1.3 reveals that among different working categories no significant difference in time allocation for elderly care can be noticed. The values presented in the table are average or mean value of time (per day) in hours.

Table 3 Time allocation (in hours) for elderly care across occupational status

\begin{tabular}{|c|l|c|}
\hline S.No & \multicolumn{1}{|c|}{ Occupational Divisions } & Elderly care time \\
\hline 1 & Legislators, Senior officials, and managers & 0.119 \\
\hline 2 & Professionals & 0.063 \\
\hline 3 & Technicians and Associate professionals & 0.191 \\
\hline 4 & Clerks & 0.099 \\
\hline 5 & Service workers and Shop \& market sales workers & 0.069 \\
\hline 6 & Skilled Agricultural and Fishery workers & 0.000 \\
\hline 7 & Craft and related workers & 0.060 \\
\hline 8 & Plant and machine operators and Assemblers & 0.000 \\
\hline 9 & Elementary occupations & 0.103 \\
\hline 10 & Workers not classified by occupations & 0.141 \\
\hline & F-value & $0.717 \mathrm{~ns}$ \\
\cline { 2 - 3 } & P-value & 0.693 \\
\hline
\end{tabular}

ns - nonsignificant at 0.05 levels

Values presented in the table are average or mean value of time (per day) in hours.

Source: Sample survey

One feature that is noticed about skilled agricultural and fishery workers, plant and machine operators is that the mean value for elderly care time nuclear with no elderly members living with them, so no elderly care and zero mean value for elderly care time. approaches zero. Two main reasons for this are that among the total samples these two groups contain lowest sample size and their households are mainly 


\section{Conclusion}

One important conclusion derived from the study is that women whatever be their employment status, they remain solely responsible for domestic work and care related-activities including both child care and elderly care. If we try to pay the price for mother's love, care for sick and elderly, it is, in fact, undervaluing women's actual contribution to the nation. By taking into consideration the moral value of love and affection provided by the working woman for the overall wellbeing of their family, my view is not to pay them a price for their love and affection, but the quantification of their economic value is necessary to know their true economic contribution to the nation.

\section{References}

Becker, Gary S. "A Theory of Social Interaction." Journal of Political Economy, 82, 1974, 1063-1094.

Becker, Gary S. "Economic Approach to Human Behaviour." University of Chicago press, Chicago: London. 1976.

Becker, Gary S. "A Treatise of the Family." Cambridge: Massachusetts: Harvard University Press, 1981.

Becker, Gary S. "Human Capital, Effort, and the Sexual Division of Labor." Journal of Labor Economics, 3(1), 1985, S33-S58.

Bianchi, Susanne M. "What gives when mothers are employed? Parental time allocation in and single earner two parent families." Department of sociology and Maryland population, Research centre, Maryland population Research Centre: Maryland, 2006.

Biddle, J. E. \& Hamermesh, D. S. "Sleep and the Allocation of Time." Journal of Political Economy, 98(5), 1990, 922-943.

Bowden, Sue \& Offer, Avner., "Household Appliances and the Use of Time: The United States and Britain Since the 1920s." The Economic History Review, New Series, 47(4), 1994, 725-748: Wiley.

Coleman, James. "Social Capital in the Creation of Human Capital." American Journal of Sociology, 94, 1988, S95-120.
Coser, Lewis., "A Greedy Institutions: Patterns of Undivided Commitment." The Free Press, New York, 1974.

Gronau, Reuben., "Leisure, Home production and work-The theory of Allocation of time Revisited." Journal of Political Economy, 85(6), 1977, 1099-1123.

Hamermesh, D. "The timing of work time: evidence from the US and Germany." Konjunkturpolitik, 42, 1996, 1- 22.

Hamermesh, D. "When we work." The American Economic Review, 88(2), 1998, 321-325 Papers and Proceedings of the Hundred and Tenth Annual Meeting of the American Economic Association.

Hamermesh, D. "The Timing of Work Time over Time.” Economic Journal, 1999, 109, 37-66.

Immaculada Garcia-Mainar, Molina, Jose Alberto \& Montuenga Victor M. "Gender difference in Child Care: Time Allocation in Five European Countries." Feminist Economics, 17(1), 2011, 119-150.

Kleitman, N. "Sleep and Wakefulness." Chicago University, Chicago Press. 1963.

Koreman, P. \&. Kapteyn, A. "A Disaggregated Analysis of the Allocation of Time within the Household." Journal of Political Economy, 95(2), 1987, 223-249.

LeVine, R. A. "Women's schooling, patterns of fertility, and child survival." Educational Researcher, 16(9), 1987, 21- 27.

Malathy, R. "Women's schooling and time allocation: Theory and empirical evidence," Seminar paper presented at the Maharaja Sayaji Rao University, Baroda, 1998.

Miller, Paul \& Mulvey, Charles. “Women's Time Allocation to Child Care: Determinants and Consequences." Australian Economic Papers, 39(1), 2000, 1-24.

Schultz, T. P. "The Fertility Revolution: A SupplyDemand Analysis - A Review Essay." Population and Development Review, 12(1), 1986, 127-140.

Visvanathan, Susan., "Women and Work - From Housewifization to Androgyny." Economic and Political Weekly, xxx1,nos 45 and 46 November 9-16. 1996. 
Waldfogel, Jane., "The Wage Effects of Children," Yamada, Tadashi \& Yamada, Tetsuji., "The American Sociological Review, 62: 1997, 209-217.

Waldfogel, Jane., "Working Mothers Then and Now: A Cross-Cohort Analysis of the Effects of Maternity Leave on Women's Pay. In Francine Blau and Ronald Ehrenberg (eds.), Gender and Family Issues in the Workplace," New York: Russell Sage, 1997.

Willis, Robert.J. "A new approach to the economic theory of fertility behavior." Journal of Political Economy, 81(2), 1973, S14-S64. Allocation of Time: Young Versus Elderly Households in Japan." NBER Working Paper No. 4386, 1993.

Zuzanek, Jiri \& Wenger, Lisa., "Changing the pattern of working hours and their implication regard to time use, time pressure and emotional wellbeing." Paper presented at the 10th Canadian Congress on leisure research, University of Alberta, Edmonton, Alberta, 2002.

\section{Author Details}

Dr.R.Ramya, Assistant Professor of Economics, Sri C. Achutha Menon Governmen College, Thrisur, Kerala, India Email ID: ramyarajeswaran@yahoo.com 